Thijs, N., \& Van de Walle, S. (2005). 'Administrative reform movements and commissions in Belgium 1848-2004', In: Public Policy and Administration, 20 (4): 38-54.

\title{
ADMINISTRATIVE REFORM MOVEMENTS AND COMMISSIONS IN BELGIUM,
}

$1848-2004$

\author{
Nick Thijs \& Steven Van de Walle \\ Public Management Institute, Katholieke Universiteit Leuven
}

Correspondence: Public Management Institute, E. Van Evenstraat 2A, 3000 Leuven, Belgium. Tel.: +32 16 32.36.01; Fax : +32 16 32.32.67; nick.thijs@ @soc.kuleuven.be, steven.vandewalle@ soc.kuleuven.be 
ADMINISTRATIVE REFORM MOVEMENTS AND COMMISSIONS IN BELGIUM, 18482004

\begin{abstract}
Current analysis of the public administration's dysfunctions in Belgium bears remarkable resemblance to the analyses made by numerous authors and commissions in the past 150 years. In this article, we provide an overview of the major administrative reform initiatives in Belgium between 1848 and 2004. We focus on a number of books and reports from the period between the mid- $19^{\text {th }}$ century and the First World War, that were the foundation for many analyses in the $20^{\text {th }}$ century. The interbellum saw the introduction of several reform commissions, and the appointment of a Royal commissioner who would introduce some of the most radical reforms ever in the Belgian civil service, the influence of which can still be felt today. After the Second World War, the focus of the reforms changed to efficiency, and later to economy. In the late 1980s, 'citizen' and 'client' became a central concept in the reform discourse. Even though the administrative reforms and reform initiatives in Belgium since 1848 are quite diverse, there is a striking consistency in the problems that have been identified as causes for administrative malfunctioning: the influence of politics and ministerial cabinets, the size of the administration, and the administration's inefficiency.
\end{abstract}


ADMINISTRATIVE REFORM MOVEMENTS AND COMMISSIONS IN BELGIUM, 18482004

\section{Introduction}

In recent years, Belgium has seen several attempts to initiate a number of substantial administrative reform projects. From a historical perspective, many of the cited reasons for success and failure of these initiatives for reforming, recreating, modernising and reengineering the country's public administration are not exactly new. Even though the Belgian civil service does not have the long history that some neighbouring countries do, some of the reforms, especially those in the $1930 \mathrm{~s}$, can easily bear the comparison with the 1854 'NorthcoteTrevelyan' Report in the UK and 1883 'Pendleton Act' in the U.S.A. (Hondeghem, 1990, p.152). The first attempts at reforming the Belgian public administration date back to the mid $19^{\text {th }}$ century ( shortly after the founding of the country). Even though focus, approach and actors in the reform have changed over time, many elements remained remarkably similar.

In this article, we describe the main events and trends in administrative reform in Belgium, starting in 1848. Our focus is on the Federal administration, and on generic reforms, i.e. reforms having regard to the entire public administration. Our analysis is based on a number of key publications, and on the reports published by the main administrative reform commissions. We show that the diagnosis of administrative malfunctioning has remained remarkably stable, and that reform proposals have always been strongly related to general evolutions in society, and, above all, in the political contingencies.

\section{Administrative reform in the early days}

\subsection{Edouard Ducpétiaux' 'Étude sur la réforme administrative' (1859)}


In 1848, the public administration became a focal point in Belgian politics for the first time, because changed political circumstances made such an attention necessary. During the first years after the Belgian independence (1831) Unionist politics ruled, whereby party-political differences were made subordinate to the common project of building the new nation. The end of Unionism as a result of the 1848 elections turned the relationship between politics and administration into a problematic issue (Depré, 1973). The rise of a party-political system made the meddling of politics in the functioning of the administration problematic, and, above all, lead to an increase of recruitment in the civil service on political or electoral grounds (Van Hooland, 2003, p.301). Complaints were already being heard in parliament on the mediocrity of the civil servants (Crabbe, 1954, p.873). The role of civil servants in politics was equally substantive, since many senior civil servants had a political mandate, a consequence of the relatively small size of the elite in the early days of the newly born Kingdom. The first reforms touching upon the administration were in fact parliamentary reforms, forcing parliamentarians to resign from their employment as civil servant (the Law on Incompatibilities 1848) (Depré, 1973, pp.74-85).

Edouard Ducpétiaux wrote one of the first studies on administrative reform in Belgium in 1859. A civil servant himself, he was a severe critic of what he considered the excessive centralisation of the Belgian central administration, which he saw as a threat to individual liberty. Studying administrative reform, he states, implies reflection on the mission and status of the state in society. He called for the installation of a commission for administrative reform (Ducpétiaux, 1955 (1859), pp.575). The overall image he gives of the functioning of the administration is not flattering one: 'C'est là surtout qu'existent les anomalies, les complications, les superfétations, les lenteurs et les entraves qui ne peuvent être bien appréciées que par ceux qui, nourris dans le sérail, en connaissent les détours "i (Ducpétiaux, 1955 (1859), p.568). He compares the central administration to a malfunctioning and even redundant machine (Ducpétiaux, 1955 (1859), p.569). 
His criticisms, and proposals for reform, mainly dealt with three aspects. First, a reform of recruiting practices, which would allow for recruitment of the most competent people and to push back political interference in the recruitment. Alternatively, if politicians want to interfere in the hierarchical day-to-day functioning of the administration, they ought to change the present civil service system to a spoils system. A second series of proposals dealt with a restructuring of the existing ministries to allow for better coordination. The third aspect moved beyond mere administrative reform. If the administration is to function properly, legislative reform is required. Excessive and confusing regulations should be abolished, and the legislator should reflect on the necessity of regulation in the field in question, and on the desirability of state interference at the central level, rather than at provincial or municipal levels (Van de Walle, 2004, p.59). These criticisms, and proposals for reform, were reproduced in Emile Greyson's 1895 study 'L'administration, son action, ses interprètes, leur physionomie, leur silhouette par un ancien rond de cuir' (The administration: its actions, expressions, aspect and faces from an insiders point of view). Like Ducpétiaux, this former director-general complained about the political influence in the recruitment and appointment processes, and the promotion procedures. Other elements include the growing influence of the ministerial cabinets and the increasing number of civil servants (Depré, 1973, p.91-93).

\subsection{Louis Wodon (1915) and Max-Leo Gérard (1922)}

Louis Wodon, a high-ranking Belgian civil servant, in 1915 wrote his 'Mémoire sur la Réforme administrative', which proposed encompassing administrative reforms. In the public administration, he makes a distinction between 'départements de contrôle' - control departments (justice, foreign affairs, sciences and arts, home affairs, agriculture, industry and labour) and 'départements de gestion' - management departments (finance-tax administration, railways, post, etc.). The latter could, according to him, be organised as industrial or commercial enterprises. 
The problem with the public administration is two-fold: not only is the institutional organisation of the administration very complicated, with scattered competences and task allocations and confusing lines of command, but there also is the problem of political influence in the recruitment of civil servants. This political influence is considered a corrupt and demoralising force in the civil service, which threatens the general interest. Ministerial cabinets were, in this respect, considered as both useless and dangerous (Crabbe, 1986, p.286). The discussion on Ministerial cabinets would become constant in the writings on the Belgian public administration and has remained a critical element in discussions about administrative reform today (see e.g. Gérard, Cattoir, and Henin, 1935, p.44-45; Vandezande, 1999; Pelgrims, 2001). The report by the legendary Royal Commissioner Camu in 1937 would find part of its inspiration in this memorandum (Depré, 1973, p.95-98). François (1998) observes that Wodon's findings were not at all new, because most of them had already featured in Ducpétiaux' 1859 book. World War I, however, kept reforms at bay.

The 1922 paper 'L'organisation interne : le gout et le rendement des administrations publiques' (The internal organisation: the style and the output of the public sector) by Max-Leo Gérard, later minister of Finance and secretary to the King, clearly shows the influence of Fayol's scientific management (Depré, 1973, p.102). This study kept the double organisational structure, which Wodon introduced. Gérard searched for ways to organise an administrative organisation in order for it to work efficiently (Van Hooland, 2003, p.302). Ministries involved in implementation could be organised following the classic hierarchical structure, but ministries with new tasks would have to be organised and structured differently.

\section{The first Commissions for administrative reform (1922 - 1928)}

\subsection{The De Haene Commission (1922-1925)}


Although Wodon had urged for a fast reform of the administration after the War, it was only in his 1921 inaugural declaration that Prime Minister Theunis stated that 'everyone will agree that the actual working conditions are defective, that the output of certain administrations is not proportionate to the number of staff employed, and that modern procedures would at the same time be more economical and effective.' (quoted in: Gérard et al., 1935, own translation). In 1922 a 'Commission technique pour l'étude des services administratifs de l'Etat' (Technical Commission for the study of the State's administrative services) was installed, that had to prepare proposals for improving business processes, savings and simplification (Royal Decree - R.D. 10/03/1922). One of its first conclusions was, however, that a radical reform of the general organisation of the public administration was not deemed necessary (Gérard et al., 1935, p.95). It should thus not come as a surprise that the Commission had little tangible impact (François, 1998). On a similar note, Henry (1923) considers much of the discourse on administrative reform superfluous, as most problems were in fact political rather than administrative.

\subsection{The Halleux Commission (1926-1928)}

A new commission was installed in 1926, the 'Commission chargée d'étudier le fonctionnement des services de l'Etat' (Commission charged with the study of the operation of the State's services), better known as the Halleux Commission (R.D. 23/02/1926). This Commission was dissolved in 1928 leaving around 100 general and specific reports. Most conclusions dealt with process reengineering and a restructuring of certain agencies and ministries. The influence of Henri Fayol and his pleas for rational organisation can be clearly discerned in the proposals (Crabbe, 1954, p.881). Capacity-based recruitment was an important element in both Commissions' reports, as were general recommendations on the remuneration of civil servants.

In 1923, Henry wrote that it was popular to denounce the increasing numbers of bureaucrats (1923, p.4), yet, the growth of the administration had not followed population growth (Henry, 
1930, p.355). The De Haene and the Halleux Commissions urged for action to reduce the size of the public sector, but little action was taken.

After WW II (1949) two further Commissions for administrative reform would be installed. In the decade before the War, however, a Royal Commissioner for Administrative Reform was appointed. This Royal Commissioner for Administrative Reform takes a very special position in Belgian administrative history.

\section{A Royal Commissioner for Administrative Reform (1936-1940)}

The commissions in the 1920s did not even manage to solve the most pressing problems. In 1935, Gérard et al. complained? about the slowness of the administration, where even the most basic tasks seemed to take ages (Gérard et al., 1935, p.58). Still, the size of the administration, and therefore the cost of the public services, was at the core of the discussions. The constant expansion of the administration was not only a result of political appointments and the tendency of administrations to expand, but also of the expansion of social and fiscal laws and of the educational system (Gérard et al., 1935, p.11). The expansion of the public sector is mainly a result of political decisions and of the public's demand for government action on new domains. Since the War, the state had begun to evolve into an 'interventionist state' (Molitor, 1974, p.22).

The most important reform of the administration was that initiated in the mid-30s. In these turbulent times, administrative reform was just one of many initiatives in the (political) reform of the Belgian state itself, heavily influenced by the international atmosphere and a general move towards a 'New Order'.

Administrative reform had become a topic for many publications and congresses. Public opinion about the administration was negative. Henry, a former high-ranking civil servant and political advisor, even devoted a separate chapter to this aspect in his 1930-book 'Administration et 
Fonctionnaires: Essai de Doctrine Administrative' (Administration and civil servants: Essay on the Administrative Doctrine).

The zeal for reforms in all fields of government led to the appointment of nine royal commissioners, one of them Louis Camu, Royal Commissioner for Administrative Reform from 1936 to 1937 and from 1938 to 1940 . During the brief interlude between his two missions, the function of royal commissioner was filled by M. Halewyck de Heusch. The Commissioner's tasks were broadly defined (organisation of departments, business processes, material conditions, staff... - R.D. 10/10/1936) but his main tasks were with the statute and recruitment of public servants, and with the administration's working conditions, since he considered civil servants themselves the pivotal element of administrative reform (un 'problème d'hommes') (Camu, 1937, p.116). While previous writers on the public administration had complained that universitytrained people were often recruited but did not always have the required competences, discussion now was on the underrepresentation of people with a university degree in the administration, and the resulting lack of technical competence, often a result of political influence in the recruitment. Many of the ideas brought forth by Camu were hardly new as they originated in the Mémoire Wodon and Ducpétiaux' writings. A profound distrust of politics was a central aspect in many administrative reform proposals in those days (Depré, 1973: 133), as was the attractiveness of the private sector. Fayol was compulsory literature in the 20s, and many public sector reformers in the 30s and early post WWII period had previous private sector experience, mostly in banking.

Camu's first, and most important, report in 1937 dealt with the statute of civil servants, which found a great deal of its inspiration in the British Civil Service (Camu, 1937). The new statute of public personnel, issued in 1937, often referred to as 'Statut Camu' was a groundbreaking innovation and tried to bring more transparency into public sector recruitment by curtailing political influence. Since then, this statute was subject to permanent incremental changes, but more fundamental changes to the 1937 'Statut' only came in 2000. One of the main achievements 
of the new statute was the installation of the Permanent Secretariat for Recruitment, inspired by the UK Civil Service Commission (Depré, 1973, p.112). In the same period, though not by Camu, the Inspection des Finances was founded (1938).

During his second mission as Commissioner from 1938 on, Camu de facto had a quasi-ministerial status. While his first mission was mainly one of study, this second one largely dealt with the implementation of the new civil servant's statute and with organisational matters. One of the landmarks still visible in Brussels sprouting from his initiatives to relieve the miserable working conditions of the administration is the 'Cité administrative', a highly modernistic administrative office complex, that would eventually be built only after the Second World War.

Why did Camu succeed where the reform commissions did not? Camu operated in an environment that had gradually been prepared for reforms, as many proposals had been written and commissions installed in preceding years. The 1930s state of political and economic crisis reminded all actors of the need for reform. Prime Minister van Zeeland had a personal interest in administrative reform, as had many other important personalities, as shown by the impressive list of personalities involved in the activities of the Centre d'études pour la réforme de l'Etat, a highlevel private institution that acted as a brain trust for the reforms in the 1930s. When Camu issued his first report, Louis Wodon, author of the 1915 Mémoire Wodon, was Chef de Cabinet of the King (1926-1938), and thus very influential. Camu's good relations with the labour unions further contributed to his success. Resistance came from the Socialist Party, which was afraid of being deprived from their possibilities for political appointments in the administration, since they had only entered government during the First World War, and thus had to catch up with the other parties in appointing their party's supporters (Molitor, 1982, p.38-40).

Camu wanted to create an efficient and effective administration in a period of great instability. Even though he never succeeded in implementing his plans in their entirety (Depré, 1973, p.122- 
123), this milestone in Belgian administrative history can bear the comparison with the 1854 'Northcote-Trevelyan' Report in the UK and 1883 'Pendleton Act' in the U.S.A. (Hondeghem, 1990, p.152).

\section{Post-War developments: economy and efficiency}

In his book 'La réforme administrative est-elle un mythe' (Is administrative reform a myth?), written in 1944, Omer Molle presents a number of suggestions to improve the functioning of the public administration (Molle, 1947). Molle had been a member of Camu's staff from 1938 on. Though he had a positive view on the administration and the civil servants, he observed abuse and saw civil servants concerned with self-interest. He was not pessimistic: administrative reform is perfectly possible, and does not require ingenious actions or plans: 'Administrative reform does not require big words or complex formulas. If it is conducted systematically, service after service, it does not imply extraordinary things, nor the solution of particularly difficult problems' (Molle, 1947, p.83, own translation). His discourse on a rational organisation of the administration is an expression of a very modernistic and optimistic state of mind. A great deal of material centralisation would solve most of the problems. The centralisation of the administration in the already planned Cité administrative would help solve one-third of all problems by installing order, systematic working procedures and better supervision.

As in most writings on the administration, no mention is made of citizens or users of the public services. The motivation for reform is mainly to reduce waste. Administrative inflation, i.e. an ever-increasing number of civil servants is identified as the main problem: in twenty years time, the number of civil servants had doubled.

\subsection{The Phillipart (Maton) (1949-52) and Gérard Commissions (1953-4)}


The end of the Second World War also meant new attempts at administrative reform. These attempts materialised in a large number of commissions dealing with specific aspects of the organisation of the public administration (Crabbe, 1954, p.895-897). Two commissions were of a general nature. In 1949, the Belgian parliament decided to install the Commission Philippart or Matton (both names are used), that had to investigate how to introduce reforms to increase efficiency and economy in the public services (Law of 01/07/1949). It was the first time such a commission was installed by law instead of by a mere (executive) royal decree.

The parliamentary debates on the law reveal some information on the public opinion towards the public administration in those days. Senator Ronse states that 'Lorsqu'on se pose la question: L'Etat est-il bien administré en ce moment, il faut répondre [...], par la négative' [If one asks oneself whether the state is well managed at this moment, one has to answer in a negative way own translation] (Belgische Senaat, 1948, p.1699). Indeed, the minister for the budget, Mr. Merlot speaks about systematic rumours in the press, the parliament, and the entire country, about the malfunctioning of the public administration (Belgische Senaat, 1948, p.1700). The installation of the commission was for the minister a means for putting these rumours and legends in the proper context, as the parliament, the press and the population, according to him, often had imprecise and false ideas about the functioning of the administration.

The successor to this commission was installed in 1953 (R.D. 25/03/1953). Again, the tasks of this Commission d'étude pour la réforme des administrations de l'Etat (Commission charged with the study on the reform of the public service) were defined very broadly: it could deal with the statute of public personnel; structure and competences of departments, techniques for management, coordination and control, etc. There was resistance against this decision, as the functioning of the administration was said to be defective only because it found itself in a period of transition, and because the bad post-war economic situation simply did not allow for many of the much-needed changes. The reduction in the number of civil servants was again part of the 
discussions, since many temporary agents had been recruited during the War. Some thought this excess would normalise itself in the post-war years. This commission presided by Max-Léo Gérard would only lead a short life.

Both commissions did not generate many results, among others because many reforms ultimately depended on political decisions. For Crabbe, the commissions were mainly window-dressing (Crabbe, 1954, p.902-903). The post-war period saw a gradual shift in the focus of attention from the statute of civil servants and the size of the public administration to concerns of economy and efficiency. The Matton Commission was the first one to have economy and proper use of public money as one of its core tasks (François, 1987, p.358-359). Most reforms in the 1950s failed. Only the early 60s saw a revitalisation of the reform zest culminating in the Gilson reform.

\subsection{A minister for Administrative Reform}

Belgium had to wait till the end of the 1950 s to see the emergence of a separate cabinet minister dealing with the public administration. Before that date, ministers were responsible for their own departments, and the prime minister for the general administration. Surprisingly, this minister (A. Lilar) had 'administrative reform' in his title. Since this Eyskens III government, public administration appears to have been institutionalised as a distinct function in government, though often in combination with other competences (Home Affairs, scientific policy, SMEs).

In 1961, Arthur Gilson became minister of the Interior and the Public Service and his term of office indicated the second time since the foundation of Belgium that serious attempts at largescale reforms were made. The main result of the Gilson reform was a modification of the statute of civil servants in 1964 (R.D. 16/03/1964). Much of the reform focused on issues that had been at the core of Camu's proposals:

- The introduction of a human resources policy

- Increasing public sector productivity 
- $\quad$ Restructuring of the government and ministerial administrations

Despite disappointing implementation, the Gilson reforms indicated the start of a HR policy in the public administration. The founding in 1962-63 of the Institute Administration-University indicates the augmented attention for civil servants' training. Few profound reforms were actually initiated (François, 1998), and it became a habit to speak about the 'Statut Gilson', because of his reform of the statute of civil servants, and not about the Gilson reform. The main topics of discontent remained the same: a politisation of the administration and a continuing expansion of the public sector.

\section{Administrative reform subordinate to institutional reform}

The end of the 60s saw some attempts to introduce PPBS in the administration, but by the end of the 70s almost all experiments had ceased (de Borchgrave and Van Den Heede-Lybaert, 1979). The state-reform, gradually transforming Belgium from a centralised, unitary state into a federal state, dominated the political agenda. Institutional reforms seem to have been detrimental for administrative reform. The 1970s remain notorious for the expansion of the public sector, where public sector employment was used as a substitute to unemployment resulting in an increase of public debt (FOD P\&O, 2003, p.5-6). Between 1971 and 1981, public sector employment increased by 30\% (François, 1999). The 1970s hardly saw any proposal for administrative reform of the central administration. The Martens II government in 1980 (which lasted not even three months) did not even have a member with a specific responsibility for the public service. At the local level, discussions on productivity and governability of municipalities culminated in a largescale merger of municipalities in 1976.

Due to the institutional reforms in the 1970s and 1980s, separate administrative structures were created for the different regions. The transfer of personnel from central (federal) ministries to regional ministries gradually took place in the mid 1980s. The logical result was the restructuring 
of the federal administration. Apart from the institutional reform (process of federalisation), government policy in the period 1981-1985 focussed on economic reconversion, securing the system of social security and balancing the budget. This approach, followed by most Western countries in those days, was fundamentally different from the expansionist approach that had been taken previously during the 1960s and 70s (François and Molitor, 1987, p.110).

\section{Administrative reforms back on the agenda (second half of the '80s)}

Financial strains and budgetary problems brought the functioning of the public administration back on the agenda. The gradual return of administrative reforms to the political agenda found its expression in a reform of the budgetary system and the first move towards informatisation of the public sector (Rapport Bodart). State Secretary for the Public Service Waltniel introduced measures promoting increased civil servant mobility, with little success, however. Guy Lutgen, State Secretary for the modernisation and informatisation of the public services from 1985 on, was one of the first to stress the central position of clients in the administration. The first objective of the Lutgen reforms was putting public services at the service of the population (Lutgen, 1986, p.14). Citizens had to be considered as clients, and not as subjects. The other core pillars of his approach were productivity and effectiveness. His plans focused on clientbureaucracy encounters: informing users, service quality, corporate image etc. In this period we see the first strong appeals for an 'école nationale' for training civil servants.

Modernisation would follow a gradual and bottom-up path by installing, in 1987, Modernisation Cells in each ministry. These cells are simple entities advising and supporting the top civil servants introducing the modernisation reforms. 'Il est clair que la responsabilité de la gestion et de la modernisation reste du ressort de la hiérarchie (...) Elle n'est pas un nouvel organe de gestion, ni un service d'études, ni une équipe de consultants internes, ni un groupe d'experts en gestion. Son rôle, orienté vers l'action, n'est pas de 'faire' mais de 'faire faire' (...)' ${ }^{\mathrm{ii}}$ (Legrand, 
1990, p.176-177). The Modernisation Cells had to help to make things happen. ABC (Advies Bureau Conseil), the new internal organisation consulting office of the federal administration would coordinate these efforts.

Minister Langendries made efforts to change the civil servants' statute, but these changes would only be implemented years later. A gradual X-ray of the business processes of the federal public services, the Radioscopie, from 1991 on, would eventually lead to a reorganisation of the Federal administration (Staes, 1992). Though it was aimed at a reform of the administration, it mainly resulted in a reduction of public sector staff (Bouckaert and Thijs, 2003). In the period 88-91 two different ministers were responsible for administrative reforms: the minister of the Interior and modernisation and the minister of civil service.

\section{The 1990s: citizens move to the core of the administration}

In his influential Burgermanifest (citizen manifesto) in 1991, liberal politician, and now PM, Verhofstadt called for an emancipation of the citizen from political, administrative, and fiscal powers that suffocated him, and he was one of the first to speak about a gap between citizen and government (kloof met de burger) (Verhofstadt, 1991). The rise of the extreme right in the 1991 elections was a shock for the political establishment. The citizen became the focus of political discourse, both as a rhetorical device and as an expression of genuine concern for quality service delivery. From the early 90 s on, the motivation for reform was no longer only to make the public sector perform better, but to remedy citizens' distrust in government. The 1990s saw not only the introduction of a service charter (1993), but also of laws organising the right of access to official documents (1994), the protection of privacy, formal motivation of administrative decisions (1991), the possibility for a preliminary injunction before the Supreme administrative court, and the installation of a Federal ombudsman (1995). 
The ongoing federalisation of the state, culminating in a state reform in 1993, also meant the start of administrative renewal in many of the newly born ministries and public administrations at the regional level. The ministry of the Flemish Community turned out to be a particularly active reformer (Bouckaert and Auwers, 1999; Van Coppenolle and Legrain, 2003).

In 1993, the Charter of the User of Public Services was introduced (KB 4 .12.1993; BS 22.01.1993). The introduction of the charter was motivated by concerns about the apparent gap between citizens and government. The introduction of the charter seems to have been a political reaction to the 1991 elections (Staes and Legrand, 1998, p.12). Political need meant that the charter was developed rather fast, with only little contribution by the administration (Bouckaert and Thijs, 2003, p.481). This explains why serious efforts had to be made to communicate the content of the charter. This Charter introduced some general principles and actions for the delivery of high quality services (Triëst, 1994; Berckx, 1993; Vermeulen, 1995; Broeckaert, 1995). Compared to the UK Charters (1991 and 1997) and the French 'Charte des services publics' (1992), where respectively the market and the state were the central concepts, the Belgian Charter focused on democracy: 'The charter, which is considered to be a permanent instrument for improvement, takes the political and administrative modernisation as its operational framework. Therefore, government as well as the citizens should focus on rights and duties simultaneously’ (Bouckaert, 1993, p.7).

In 1994, changes were made to the statute of civil servants. The reason for reforming the statute was the process of federalisation. From 1988 on, each region was responsible for organising its personnel policy autonomously. At the central level only some general principles were stipulated. Also in 1994, the government agreed on the introduction of a mandate system for top civil servants, aiming at giving these civil servants more responsibility (Hondeghem, 1990, p.194195). This system was officially introduced in 1999. It was only in 1995, that a Ministry for the Public Administration was founded, as a horizontal ministry providing services to other ministries and preparing and executing human resources policy. Until then the competence of administrative 
reform was part of the ministry of Interior. Not until 1997 was this ministry fully operational (Bouckaert and Wauters, 1999, p.24-29).

\section{The Copernicus reform as a new milestone}

At the federal level, the 'Copernicus reform programme' started in 1999 as a holistic reform programme integrating all scattered aspects of previous reforms. This reform initially focused on citizen-oriented reform-initiatives. The project started with a nation-wide survey, which was in fact a PR-initiative (Gelders and Van de Walle, 2005), informing and consulting citizens on the federal reinvention initiative. Attention had somewhat shifted from strict managerial reforms to aspects of citizen involvement and quality of service delivery. Even though a User Charter had been introduced in 1993, attention for the citizen, be it in reality or only in political discourse, has coincided with the coming to power of a liberal-socialist-green government in 1999. In fact, the name of the federal reform initiative Copernicus was chosen for its symbolic value: whereas the Polish astronomer Nicolaus Copernicus claimed that the earth was rotating around the sun instead of the other way around, the Copernicus reform initiative wanted to stimulate awareness that the administration is rotating around the citizen, and not, as had been the case in the past, that the citizen rotates around the administration: 'Without citizens, the administration has no reason to exist'.

A diagnosis performed by consultants of the federal administration showed that the organization by 1999 was paralyzed by redundant procedures, had top civil servants who lacked the qualities and the autonomy to manage, was populated by demotivated staff and bore a culture of distrust towards change. Above that, the administration was faced with a massive legitimacy problem (Van de Walle, Thijs et al., 2005).

Two major goals were set: the federal administration had to become a better employer for its civil servants and secondly, the federal administration had to provide a better service to its 'clients': 
the citizens. These two goals would be achieved by major changes in four domains. First of all a new organization structure had to be designed. Due to the process of federalization and the growing autonomy for many matters of the different regions in Belgium, from the late ' $70 \mathrm{~s}$ onwards, the organizational structure of the federal administration was outdated. The Belgian federal administration was composed by classical ministries and counted 60.000 civil servants. The old structure was abandoned and 14 new ministries or Federal Government Services (FGS) were created. These FGSs were integrated in a 'virtual matrix' with 4 horizontal FGSs (Personnel and Organization, ICT, Budget and the Services of the Prime Minister) and 10 vertical FGSs (Internal Affaires, Social Security, Labour and Pensions, Economy...).

The structural reorganization was supplemented by attempts at creating a new management culture. All senior appointments became subject to assessments, and a mandate system for senior civil servants was introduced. The 'managers' were given more autonomy, but their appointment was now limited to a (renewable) 6-year term. During this period of assessments the political resistance increased, and the differences between Flemish and French speaking parties became clear (Thijs, 2005). A new HR policy was launched based on developing and valuing civil servants' expertise and the process of recruitment and selection was redesigned. Finally, there was a generalised adoption of business re-engineering techniques. In 1999, the Verhofstadt I government had a minister for the civil service and the modernisation of the administration, a title indicating the attention for the reform of the administration. In 1999, and in 2003 (Verhofstadt II government) we see the emergence of new terminology: a government commissioner (19992000) and state secretary (from 2003 on) for administrative simplification. This is due to the entrance of the liberal party (parties) in government, which had made administrative simplification a major element in their political programmes. At the same time, these governments also had a government commissioner or state secretary for the simplification of fiscal procedures. Surprisingly, modernisation of the administration disappears from the title of the minister for the civil service in 2003. The dynamic of the first years of the reform slowly 
faded and resistance increased, both politically and from the side of the labour unions. Some parts of the reform have been reduced or reversed.

\section{Conclusion: 150 years of administrative reform}

The first studies about the functioning of the Belgian administrative system date from the mid $19^{\text {th }}$ century. These studies were written by civil servants, with Ducpétiaux' book in 1859 as one of the masterpieces. From 1922 on, a whole series of specialised commissions was installed to study and improve the functioning of administration. Some were more successful than others. An important milestone in Belgian administrative history was the introduction of a formal and legal statute by Royal Commissioner Camu (1937). Apart from some changes in the 1960s by Gilson and recently in 2000 , the guiding principles of the statute still remain at this time. The practice of using commissions fell into disuse by the end of the 1950s, early 1960s, coinciding with the installation in 1958 of the first government with a cabinet minister with an explicitly stated competence for the public administration and administrative reform. Administrative reform disappeared from the agenda in the 1970s due to the institutional reforms transforming Belgium into a Federal state. The dreadful economic situation lead to a massive increase in public sector employment, and later, in the 1980s, to a need for savings. Reforms resumed by the end of the 1980s with the installation of modernisation cells, leading to incremental bottom-up change. The 1990s saw the start of many new reform initiatives including the introduction of the User charter, and the foundation of a ministry for the public administration. Our overview concluded with the major Copernicus reform, which began in 1999.

Our analysis revealed two main trends: one is that the same issues have cropped up in almost every analysis of the administration's malfunctioning in the last 150 years. Yet, the overall focus 
in the reform projects has changed. The other trend is that the most fundamental administrative changes occurred in times of political change.

Even though the administrative reforms and reform initiatives in Belgium since 1848 are quite diverse, there is a striking consistency in the problems that have been identified as causes for administrative malfunctioning: the influence of politics and ministerial cabinets, the size of the administration, and the administration's defective efficiency. Yet, the principal focus of reform has gradually changed. Where concerns originally had to do with excessive political influence in the administration, insufficient expertise, and an ever-expanding administration, we gradually saw efficiency considerations enter the debate. Economy and savings were core elements in the 1980s, and the 1990s were the era of the citizen-customer.

Another observation related to the joint occurrence of political and administrative reform. Most substantial administrative reform occurred in periods of political change, or in periods of great social and/or economical pressure. Administrative reform, it seems, does not enter the political agenda on its own merit. Its entrance is stimulated by other factors. Ducpétiaux used administrative reform to refer to reforms both in the political and in the administrative sphere in his study on administrative reform in the 19th century. The reforms in the 30 s resulting in the statut Сати were also to a large extent motivated by the discontent with the organisation of the political system at large. The reforms came at the height of internationally turbulent political and economic times. The economic crisis made reform possible, since the large bureaucratic apparatus was draining much of the state funds. Increased attention for administrative reforms from the 60 s on coincided with appeals for granting more autonomy to the regions. The reappearance of reforms on the agenda in the 1980s occurred because of large budgetary deficits. Some large scale scandals in the mid 90 s revealed the malfunctioning of the courts and police, and support for reforms of these institutions certainly spilled over to support for administrative reform in general. 


\section{Bibliography}

Belgische Senaat (1948), Wetsontwerp tot instelling van een Gemengde Commissie van Onderzoek naar de Werking van de Rijksdiensten en de Parastatale Instellingen - Algemene Behandeling, Parlementaire Handelingen 13 juli.

Berckx, P. (1993), 'De bestuurlijke vernieuwing en het Handvest van de Gebruiker van de openbare diensten', Tijdschrift voor Bestuurswetenschappen en publiekrecht, No 5, pp 275-288.

Bouckaert, G. (1993), Charters as frameworks for awarding quality: the Belgian, British and French experience, Seminar on concepts and methods of quality awards in the public sector, Speyer, Germany, October 21-22.

Bouckaert, G., and Auwers, T. (1999), De modernisering van de Vlaamse Overheid. Overheidsmanagement $n r$ 2, (Brugge: die Keure).

Bouckaert, G., and Thijs, N. (2003), Kwaliteit in de Overheid, Een handboek voor kwaliteitsmanagement in de publieke sector o.b.v. een internationaal comparatieve studie, (Brussel: Academia Press).

Bouckaert, G., and Wauters, A. (1999), Moderniseringsinitiatieven binnen de federale overheid: organisatie, (Brussel: DWTC).

Broeckaert, M.(1995), Het Handvest van de Gebruiker van de openbare diensten, (Brussel: Ministerie van Ambtenarenzaken). 
Camu, L. (1937), Le statut des agents de l'Etat: premier rapport sur la réforme administrative, (Bruxelles: IMIFI).

Crabbe, V. (1954), 'Les commissions de réforme administrative en Belgique', Revue Internationale des Sciences Administratives, No 4, pp 869-905.

Crabbe, V. (1986), 'Chronique d'histoire de l'administration: le mémoire de Louis Wodon sur la réforme administrative ou l'intérêt qu'il y a de replacer cette oeuvre en son temps', Administration Publique: Revue du Droit Public et des Sciences Administratives, No 4, pp 269-294.

de Borchgrave, R., and Van Den Heede-Lybaert, A. (1979), Het Belgisch P.P.B.S.- experiment: Beschrijving, analyse en evaluatie, (Brussel: Instituut Administratie-Universiteit).

Depré, R. (1973), De topambtenaren van de ministeries in België, (Leuven: K.U.Leuven, Faculteit Sociale Wetenschappen).

Ducpétiaux, E. (1955 (1859)), 'Etude sur la réforme administrative', Revue Internationale des Sciences Administratives, Vol 21, No 3, 566-590.

Federale Overheidsdienst Personeel en Organisatie (2003), Nota aan de regeringsonderhandelaars en de nieuwe regering, (Brussel, FOD $\mathrm{P} \& \mathrm{O})$.

François, A. (1987), 'La modernisation de l'administration de l'Etat en Belgique', Revue Internationale des Sciences Administratives, Vol 53, No 3, 355-399. 
François, A. (1998), Histoire de la réforme administrative avant 1937, (Louvain-la-Neuve: AURA).

François, A. (1999), Projet de recherche sur la modernisation des services publics fédéraux en Belgique: Rapport provisoire sur la gestion de la fonction publique, (Louvain-la-Neuve: AURA).

François, A. and Molitor, A. (1987), 'L'administration belge de 1970 à ce jour', Administration Publique, Vol 11, No 2/3, pp 99-123.

Gelders, D., and Van de Walle, S. (2005), 'Marketing government reforms', Journal of Non profit and Public Sector Marketing, Vol 14, No 1/2.

Gérard, M. (1922), L'organisation interne: le gout et le rendement des administrations publiques, (Bruxelles: Goemaere).

Gérard, M.-L., Cattoir, F., and Henin, Z. (1935), Etudes sur la réforme des services administratifs de l'Etat, (Bruxelles: Editions du Comité Central Industriel de Belgique).

Greyson, E. (1895), L'administration: ses faits et gestes; ses conditions à travers les âges; son action; ses interprêtes: leur physionomie, leur silhouette, etc., par un ancien rond de cuir, (Bruxelles: Ch. Rozez; imprimerie Van Assche et Cie).

Henry, A. (1923), La réforme administrative, (Bruxelles: Goemaere).

Henry, A. (1930), Administration et fonctionnaires: essai de doctrine administrative, (Bruxelles: Maurice Lamertin). 
Hondeghem, A. (1990), De loopbaan van de ambtenaar. Tussen droom en werkelijkheid, (Leuven: VCOB).

Legrand, J.-J. (1990), 'L'approche belge de la modernisation des administrations publiques: les cellules de modernisation comme outil stratégique de changement', Administration Publique, Bruxelles, Vol 14, No 2-3, pp 169-188.

Lutgen, G. (1986), Stratégie d'actions prioritaires pour la modernisation des services publics, (Bruxelles: Secretariat d'Etat à la Modernisation et a l'Informatisation des Services Publics).

Molitor, A. (1974), L'administration en Belgique, (Bruxelles: Institut belge de Science Politique \& CRISP).

Molitor, A. (1982), Servir L'Etat: Trois expériences, (Louvain: Association Universitaire de Recherche en Administration - A.U.R.A.).

Molle, O. (1947), La réforme administrative est-elle un mythe? (Bruxelles: M. Weissenbruch Soc. An.).

Pelgrims, C. (2001), Ministeriële kabinetsleden en hun loopbaan. Tussen mythe en realiteit. (Brugge: Die Keure).

Staes, P. (1992), De methodologie van de doorlichting, In: De Mesmaeker, M., Naar een beter en budgettair beheer in België. Nieuwe perspectieven vanuit de operatie Doorlichting, (Brussel: $\mathrm{ABC})$. 
Staes, P., and Legrand, J.-J. (1998), Het handvest van de gebruiker van de openbare diensten, (Brussel: Federaal Ministerie van Ambtenarenzaken/Labor).

Triëst, V.(1994), La Charte de l'utilisateur des services publics, (Bruxelles: ABC).

Thijs, N. (2005), De Copernicushervorming het verhaal: chronologie van politieke en bestuurskundige feiten, In: Hondeghem, A., and Depré, R. (red.), De Copernicushervorming in perspectief. Veranderingsmanagement bij de federale overheid, (Brugge:Vanden Broele).

Vancoppenolle, D., and Legrain, A. (2003), 'Le new public management en Belgique: Comparaison des réformes en Flandre et en Wallonie', Administration publique, No 2, pp 112128.

Verhofstadt, G. (1991), Burgermanifest, (Gent).

Van de Walle S. (2004), Perceptions of administrative performance: the key to trust in government? (Leuven: K.U.Leuven, Faculteit sociale wetenschappen, Departement Politieke Wetenschappen).

Van de Walle, S., Thijs, N., and Bouckaert, G. (2005), 'A tale of two charters: Political crisis, political realignment and administrative reform in Belgium', Public Management Review, Vol 7, No 3, pp 367-390. 
Vandezande, J. (1999), Ministeriële kabinetten. De ontwikkeling en het profiel tijdens de periode 1918-1969, (Leuven: K.U.Leuven, diss. lic. politieke wetenschappen).

Van Hooland, B. (2003), Nieuw publiek management: van bestuurskunde tot Copernicus, (Gent: Academia Press).

Vermeulen, P. (1995), 'Kwaliteitszorg, prestatiegerichtheid en klantvriendelijkheid binnen het federaal openbaar ambt: een overzicht van de reeds genomen initiatieven', Tijdschrift voor Bestuurswetenschappen en Publiek Recht, No 6, pp 297-303.

\section{Legal texts}

Koninklijk Besluit van 10 maart 1922 tot instelling van een technische commissie voor de studie van 's Staats bestuursdiensten, B.S. 13-14/03/1922, pp 2217-18.

Koninklijk Besluit van 23 februari 1926 tot instelling van een Commissie belast met de studie van de werkwijze der Staatsdiensten, B.S. 24/02/1926, pp 875-879.

Koninklijk Besluit van 10 oktober 1936 tot benoeming van koninklijke commissarissen, B.S. 11/10/1936, pp 6446-47.

Koninklijk Besluit van 2 oktober 1937 tot het statuut van het rijkspersoneel, B.S. 8/10/1937, p 6074.

Koninklijk besluit van 30 maart 1939 tot instelling van een Dienst van Algemeen Bestuur, B.S. 02/04/1939, pp 2156-57. 
Koninklijk Besluit van 25 maart 1953 tot oprichting van een Studiecommissie voor de hervorming van de Rijksbesturen, B.S. 27/03/1953, pp 1868-69.

Koninklijk Besluit van 16 maart 1964 tot wijziging van het koninklijk besluit van 2 oktober 1937 en van sommige andere besluiten betreffende het statuut van het Rijkspersoneel, B.S. 25/03/1964.

Koninklijk Besluit van 4 december 1992 betreffende Handvest van de Gebruiker van de Openbare diensten, B.S. 22.01.1993, p 1150.

Wet van 1 juli 1949 tot instelling van een gemengde commissie van onderzoek naar de werking van de Rijksdiensten en parastatale instellingen, B.S. 06/07/1949.

\footnotetext{
$\mathrm{i}$ "It is there especially that the anomalies, the complications, the excesses, the inertia and the obstructions exist. These can only be appreciated by those who were raised in the serail, and know their way around them" (own translation)

ii "It may be clear that the responsibility for management and modernization remains the responsibility of the hierarchy (...) It is not a new management body, nor a study department, nor a team of internal consultants, nor a group of experts in management. Its role, directed towards action, is not to 'act' by itself, but to create the circumstances, which make it possible for other to act" (own translation)
} 